\title{
AKULTURASI ISLAM DAN BUDAYA LOKAL PADA TRADISI BONGKAR BUMI DI DESA CUPANG KECAMATAN GEMPOL KABUPATEN CIREBON
}

\author{
Endah Maryamah ${ }^{1}$, Etty Ratnawati ${ }^{2}$ \\ IAIN Syekh Nurjati Cirebon ${ }^{1,2}$ \\ maryamahendah@gmail.com,ettyratnawati69@gmail.com
}

\begin{abstract}
Abstrak
Di dalam keberagamaan masyarakat muslim tidak bisa lepas dari tradisi lokal yang hidup dan berkembang sesuai dengan keadaan masyarakat setempat, dimana mereka hidup, berkomunikasi dan beradaptasi sesuai dengan lingkungan yang ada. Proses penyebaran agama Islam yang ada di Nusantara tidak pernah terlepas dari proses akulturasi budaya, Seperi tradisi Bongkar Bumi yang berakulturasi dengan kebudayaan Islam yang sampai sekarang masih tetap eksis dilaksanakan dan sudah mendarah daging serta menjadi rutinitas bagi masyarakat Cupang pada setiap tahunnya. Tujuan dari penelitian ini adalah untuk mendeskripsikan bagaimana acara budaya lokal tradisi bongkar bumi di desa Cupang, apa bentuk dan wujud akulturasi Islam yang terdapat pada tradisi bongkar bumi di desa Cupang, dan bagaimana persepsi masyarakat terhadap budaya lokal tradisi bongkar bumi di desa Cupang. Penelitian ini bersifat kualitatif dengan jenis penelitian yang digunakan adalah penelitian lapangan. Pengumpulan data dilakukan dengan mengadakan observasi secara menyeluruh, wawancara dan dokumentasi untuk mendapatkan informasi mengenai masalah yang diteliti. Hasil penelitian menujukan bahwa dalam tradisi bongkar bumi menunjukan adanya bentuk akulturasi budaya Islam yang terdapat pada rangkaian upacara tradisi bongkar bumi tersebut dimana dalam rangkaian upacara bongkar bumi tersebut terdapat perpaduan antara budaya Hindu dan budaya Islam. Seperti yang dapat dilihat dari bentuk do'a yang dikolaborasikan dengan kalimat- kalimat jawa dan dipadukan dengan kalimat-kalimat do'a yang bernuansa Islami, Kemudian hiburan yang ada dalam tradisi bongkar bumi adalah wayang kulit, yang merupakan salah satu bentuk akulturasi antara buday Hindu-Budha dengan Islam.
\end{abstract}

\section{Kata Kunci: Akulturasi, Islam, Budaya Lokal}

\begin{abstract}
In the diversity of Muslim communities can not be separated from local traditions that live and develop in accordance with the circumstances of the local community, where they live, communicate and adapt according to the
\end{abstract}


environment. The process of spreading the religion of Islam in the archipelago has never been separated from the process of cultural acculturation, Like the Bongkar Bumi tradition which is acculturated with Islamic culture which still exists and has been ingrained and has become a routine for the Betta community every year. The purpose of this study was to describe how the local cultural tradition of the Bongkar Bumi tradition in Cupang village, what form and form of Islamic acculturation contained in the tradition of Bongkar Bumi in Cupang village, and how people's perceptions of the local culture of the Bongkar Bumi tradition in Cupang village. This research is qualitative with the type of research used is field research. Data collection is carried out by conducting comprehensive observations, interviews and documentation to obtain information about the problem under study. The results of the study show that in the tradition of unloading the earth shows the form of acculturation of Islamic culture contained in the series of bongkar bumi traditional ceremonies where in the series of bongkar bumi ceremonies there is a combination of Hindu culture and Islamic culture. As can be seen from the form of prayers that are collaborated with Javanese sentences and combined with Islamic prayer sentences, then the entertainment that exists in the Bongkar Bumi tradition is wayang kulit, which is a form of acculturation between Hindu culture -Budha with Islam.

\section{Keywords: Acculturation, Islam, Local Culture}

\section{A. PENDAHULUAN}

\section{Latar Belakang Masalah}

Berdasarkan observasi awal bahwa masyarakat desa Cupang merupakan salah satu daerah yang ada di kecamatan Gempol kabupaten Cirebon yang masyarakatnya masih melakukan adat istiadat (tradisi) dan mempunyai kepercayaan terhadap tempat yang dianggap keramat. Tradisi yang masih dilakukan terutama mengenai tradisi selamatan seperti tradisi Bongkar Bumi.

Tradisi bongkar bumi merupakan bentuk upacara tradisional yang dilaksanakan oleh warga masyarkat desa Cupang sebagai ritual sekaligus ekspresi budaya untuk menyambut musim tanam yang ada ditengah masyarakat. Bongkar bumi dilaksanakan dengan mengadakan pengajian di mesjid dan pementasan wayang kulit di hulu dayeuh yang merupakan bentuk penghormatan terhadap karuhun yang akan memberkati desa. Dalam konteks akulturasi budaya. Ritual ini dapat dikatakan sebagai perpaduan antara islam dengan budaya lokal, dalam konteks yang lebih sederhana bongkar bumi 
adalah ritual selamatan bumi dalam memohon perlindungan dan kesejahteraan dari yang maha hidup.

Upacara bongkar bumi juga merupakan bentuk rasa syukur warga masyarakat kepada Tuhan yang Maha Esa dan Rasul-Nya yang telah melimpahkan karunia yang telah diberikan. Bagi para petani, tradisi bongkar bumi bukan hanya sekedar rutinitas atau ritual yang sifatnya tahunan. Akan tetapi, tradisi bongkar bumi mempunyai makna mendalam. Selain mengajarkan rasa syukur tradisi bongkar bumi juga mengajarkan pada kita bahwa manusia harus hidup harmonis dengan alam semesta. Tradisi bongkar bumi menurut masyarakat desa Cupang sebagai salah satu simbol yang menujukan rasa cinta dan kasih sayang dan sebagai penghargaan manusia atas bumi yang telah memberi kehidupan bagi manusia. Sehingga denga begitu maka tanah yang dipijak tidak akan marah seperti tanah longsor, bajir, dan bisa bersahabat bersandingan dengan masyarakat yang menempatinya.

Setelah Islam datang banyak sekali unsur-unsur Islam yang masuk dan dijadikan bagian dari ritual tradisi bongkar bumi. Seperti melakukan pengajian di mesjid dan puji-pujian kepada Tuhan Yang Maha Esa dan Rasul Nya sebelum pementasan wayang di hulu dayeuh. Akan tetapi, masyarakat dalam melaksanakan tradisi bongkar bumi masih melakukan ritual-ritual yang merupakan ajaran Hindu Budha. Dan masih meletakan sesajen ditempat-tempat yang dianggap keramat oleh masyarakat desa Cupang. Padahal ritual-ritual dan sesajen seperti itu tidak ada dalam syariat Islam. Sehingga dalam penelitian ini dapat diketahui bentuk-bentuk akulturasi Islam dan akulturasi Hindu Budha pada tradisi bongkar bumi yang masih bertahan dan dijalanakan oleh masyarkat desa Cupang. Maka penulis memandang perlu melakukan penelitian lebih lanjut dengan judul "Akulturasi Islam dan Budaya Lokal Pada Tradisi Bongkar bumi di Desa Cupang Kecamatan Gempol Kabupaten Cirebon”.

\section{Rumusan Masalah}

Berdasarkan latar belakang masalah yang telah diuraikan diatas, maka dapat dirumuskan beberapa pertanyaan sebagai berikut:

a. Bagaimana acara budaya lokal tradisi bongkar bumi di desa Cupang kecamatan Gempol kabupaten Cirebon? 
b. Apa saja bentuk dan wujud akulturasi Islam yang terdapat pada tradisi bongkar bumi di desa Cupang kecamatan Gempol kabupaten Cirebon?

c. Bagaimana persepsi masyarakat terhadap budaya lokal tradisi bongkar bumi di desa Cupang kecamatan Gempol kabupaten Cirebon?

\section{Tujuan Penelitian}

Berdasarkan rumusan masalah di atas, maka yang menjadi tujuan dari penelitian ini adalah sebagai berikut:

a. Untuk mengetahui budaya lokal tradisi bongkar bumi di desa Cupang kecamatan Gempol kabupaten Cirebon.

b. Untuk mengetahui bentuk dan wujud akulturasi islam yang terdapat pada tradisi bongkar bumi yang terdapat di desa Cupang kecamatan Gempol kabupaten Cirebon.

c. Untuk mendeskripsikan persepsi masyarakat terhadap budaya lokal tradisi bongkar bumi di desa Cupang kecamatan Gempol kabupaten Cirebon?

\section{B. KAJIAN TEORI}

\section{Akulturasi Islam}

Akulturasi adalah suatu proses sosial, yang timbul karena suatu kelompok manusia dengan kebudayaan tertentu dihadapkan dengan unsur dari suatu kebudayaan asing. Kebudayaan asing itu lambat laun diterima dan diolah ke dalam kebudayaannya sendiri tanpa menyebabkan hilangnya unsur kebudayaan kelompok itu sendiri. Atau bisa juga di definisikan sebagai perpaduan antara kebudayaan yang berbeda yang berlangsung dengan damai dan serasi. Untuk memahami pengertian akulturasi dalam konteks budaya pertama-tama kita perlu memahami definisi budaya dan kebudayaan terlebih dahulu. Menurut Sachari (2007:40) kebudayaan adalah suatu totalitas dari proses dan hasil segala aktivitas suatu bangsa dalam bidang estetis, moral, dan ideasional yang terjadi melalui proses integrasi, baik integrasi historis maupun pengaruh jangka panjangnya. Para ahli ilmu sosial mengartikan konsep kebudayaan itu dalam arti yang amat luas yakni meliputi seluruh aktivitas manusia dalam kehidupannya, yaitu keseluruhan sistem gagasan, 
tindakan dan hasil karya manusia dalam rangka kehidupan masyarakat yang dijadikan milik dari manusia dengan belajar (Koentjaraningrat, 1985: 180).

Akulturasi meliputi fenomena yang timbul sebagai hasil, jika kelompok-kelompok manusia yang mempunyai kebudayaan yang berbedabeda bertemu, dan mengadakan kontak secara terus menerus, yang kemudian menimbulkan perubahan dalam pola kebudayaan yang original dari salah satu kelompok atau kedua-duanya. Suyono (1985:15, menyatakan bahwa akulturasi merupakan pengambilan atau penerimaan satu atau beberapa unsur kebudayaan yang saling berhubungan atau bertemu.

Jadi dapat disimpulkan bahwa akulturasi adalah bersatunya dua kebudayaan atau lebih sehingga membentuk kebudayaan baru tanpa menghilangkan unsur kebudayaan asli. Akulturasi lahir apabila kontak antara dua kebudayaan atau lebih itu berlangsung terus menerus dengan intensitas yang cukup. Akulturasi sebagai akibat kontak kebudayaan ini dapat terjadi dalam salah satu kebudayaan pesertanya tetapi dapat pula terjadi di dalam kedua kebudayaan yang menjadi pesertanya.

Berkembangnya kebudayaan Islam di Kepulauan Indonesia telah menambah khasanah budaya nasional Indonesia, serta ikut memberikan dan menentukan corak kebudayaan bangsa Indonesia. Akan tetapi karena kebudayaan yang berkembang di Indonesia sudah begitu kuat di lingkungan masyarakat maka berkembangnya kebudayaan Islam tidak menggantikan atau memusnahkan kebudayaan yang sudah ada. Dengan demikian terjadi akulturasi antara kebudayaan Islam dengan kebudayaan yang sudah ada. Akulturasi adalah suatu proses sosial yang timbul apabila suatu kelompok manusia kebudayaan tertentu diharapkan dengan unsur-unsur dari kebudayaan asing dengan sedemikian rupa, sehingga unsur-unsur kebudayaan asing itu lambat laun diterima dan tanpa menyebabkan hilangnya kepribadian kebudayaan itu sendiri.

Islam merupakan salah satu agama yang masuk dan berkembang di Indonesia. Sebelum Islam masuk dan berkembang, Indonesia sudah memiliki corak kebudayaan yang dipengaruhi oleh agama Hindu dan Budha. Dengan masuknya Islam, Indonesia kembali mengalami proses 
akulturasi kebudayaan karena percampuran bangsa-bangsa dan saling mempengaruhi yang melahirkan kebudayaan baru yaitu kebudayaan Islam Indonesia. Hasil proses akulturasi antara kebudayaan praIslam dengan ketika Islam masuk tidak hanya berbentuk fisik kebendaan seperti seni bangunan, seni ukir atau pahat, dan karya sastra tetapi juga menyangkut pola hidup dan kebudayaan non fisik lainnya.

\section{Budaya Lokal}

Budaya adalah suatu cara hidup yang berkembang dan dimiliki bersama oleh sebuah kelompok orang dan diwariskan dari generasi ke generasi. Budaya terbentuk dari banyak unsur yang rumit, termasuk sistem agama dan politik, adat istiadat, bahasa, perkakas, pakaian, bangunan, dan karya seni. Bahasa, sebagaimana juga budaya, merupakan bagian tak terpisahkan dari diri manusia sehingga banyak orang cenderung menganggapnya diwariskan secara genetis. Ketika seseorang berusaha berkomunikasi dengan orang-orang yang berbeda budaya dan menyesuaikan perbedaan-perbedaannya, membuktikan bahwa budaya itu dipelajari.

Budaya adalah suatu pola hidup menyeluruh. budaya bersifat kompleks, abstrak, dan luas. Banyak aspek budaya turut menentukan perilaku komunikatif. Unsur-unsur sosio-budaya ini tersebar dan meliputi banyak kegiatan sosial manusia. Dalam sudut pandang Antropologi kebudayaan adalah seluruh system gagasan dan rasa, tindakan serta karya yang dihasilkan manusia dalam kehidupan bermasyarakat yang dijadikan miliknya dengan belajar.

Budaya menjadi suatu ciri khas suatu bangsa yang akan membuat bangsa tersebut dikenal oleh setiap orang baik di dalam maupun di luar negri. Setiap Negara memiliki budayanya masing-masing yang membuat Negara tersebut unik dan memiliki nilai. Bahkan ada Negara yang mempunyai banyak bangsa seperti Indonesia yang merupakan Negara yang terdiri dari banyak pulau dan bangsa serta setiap bangsa memiliki budaya khas daerah tersebut yang sering disebut sebagai budaya local.

Budaya lokal biasanya didefinisikan sebagai budaya asli dari suatu kelompok masyarakat tertentu. Menurut J.W. Ajawaila, budaya lokal adalah 
ciri khas budaya sebuah kelompok masyarakat lokal. Akan tetapi, tidak mudah untuk merumuskan atau mendefinisikan konsep budaya lokal. Menurut Irwan Abdullah, definisi kebudayaan hampir selalu terikat pada batas-batas fisik dan geografis yang jelas. Misalnya, budaya Jawa yang merujuk pada suatu tradisi yang berkembang di Pulau Jawa. Oleh karena itu, batas geografis telah dijadikan landasan untuk merumuskan definisi suatu kebudayaan lokal. Namun, dalam proses perubahan sosial budaya telah muncul kecenderungan mencairnya batas-batas fisik suatu kebudayaan. Hal itu dipengaruhi oleh faktor percepatan migrasi dan penyebaran media komunikasi secara global sehingga tidak ada budaya lokal suatu kelompok masyarakat yang masih sedemikian asli.

Menurut Geertz (1981) dalam bukunya Aneka Budaya dan Komunitas di Indonesia yang diterjemahkan oleh A Rahman Zarnuddin, di Indonesia saat ini terdapat lebih 300 dari suku bangsa yang berbicara dalam 250 bahasa yang berbeda dan memiliki karakteristik budaya lokal yang berbeda pula. Wilayah Indonesia memiliki kondisi geografis dan iklim yang berbeda-beda. Misalnya, wilayah pesisir pantai Jawa yang beriklim tropis hingga wilayah pegunungan Jayawijaya di Provinsi Papua yang bersalju. Perbedaan iklim dan kondisi geografis tersebut berpengaruh terhadap kemajemukan budaya lokal di Indonesia.

Kemajemukan budaya lokal di Indonesia tercermin dari keragaman budaya dan adat istiadat dalam masyarakat. Suku bangsa di Indonesia, seperti suku Jawa, Sunda, Batak, Minang, Timor, Bali, Sasak, Papua, dan Maluku memiliki adat istiadat dan bahasa yang berbeda-beda. Setiap suku bangsa tersebut tumbuh dan berkembang sesuai dengan alam lingkungannya. Keadaan geografis yang terisolir menyebabkan penduduk setiap pulau mengembangkan pola hidup dan adat istiadat yang berbedabeda. Misalnya, perbedaan bahasa dan adat istiadat antara suku bangsa Gayo-Alas di daerah pegunungan Gayo-Alas dengan penduduk suku bangsa Aceh yang tinggal di pesisir pantai Aceh.

Jadi budaya lokal dapat diartikan sebagai nilai-nilai lokal hasil budi daya masyarakat dari suatu daerah yang terbentuk secara alami serta 
diperoleh melalui proses pembelajaran dari waktu ke waktu yang diwariskan secara turun temurun. Budaya tersebut bisa berupa tradisi, hukum adat, pola pikir, dan hasil seni seperti tari, pahat, nyanyian dan sebagainya. Budaya local juga bisa berarti budaya yang berkembang di daerah-daerah yang merupakan milik suku-suku bangsa di wilayah Negara tersebut.

\section{Tradisi Bongkar Bumi}

Hasan Hanafi (dalam buku Moh Nur Hakim, 2003:29) mendefinisikan bahwa, Tradisi (Turats) merupakan segala warisan masa lampau yang masa pada kita dan masuk dalam kebudayaan yang sekarang berlaku. Pandangan Hanafi bahwa turats itu tidak hanya peninggalan sejarah, tetapi juga sekaligus merupakan persoalan zaman kini dengan berbagai tingkatannya. Tradisi adalah kebiasaan yang turun temurun dalam suatu masyarakat. Tradisi merupakan mekanisme yang dapat membantu untuk memperlancar perkembangan pribadi anggota masyarakat, misalnya dalam membimbing anak menuju kedewasaan.

Bongkar bumi merupakan ritual sekaligus ekspresi budaya untuk menyambut musim tanam yang ada ditengah masyarakat suku Jawa dan Sunda. Bongkar bumi dilaksanakan dengan mengadakan pengajian di mesjid dan pementasan wayang kulit di hulu dayeuh yang merupakan bentuk penghormatan terhadap karuhun yang akan memberkati desa. Dalam konteks akulturasi budaya. Ritual ini dapat dikatakan sebagai perpaduan antara islam dengan budaya local, dalam konteks yang lebih sederhana Bongkar Bumi adalah ritual selamatan bumi dalam memohon perlindungan dan kesejahteraan dari yang maha hidup, melihat di zaman sekarang ini negeri kita tengah dilanda krisis yang berkepanjangan yang melenceng dari hukum-hukumnya.

Masyarakat jawa memang terkenal dengan beragam jenis tradisi atau budaya yang ada di dalamnya. Baik tradisi cultural yang semuanya ada dalam tradisi atau budaya jawa tanpa terkecuali. Dari beragam macamnya tradisi yang ada di masyarakat jawa, hingga sangat sulit untuk mendeteksi serta menjelaskan secara rinci terkait dengan jumlah trasi kebudayaan yang ada dalam masyarakat jawa tersebut. Salah satu tradisi masyarakat jawa 
yang hingga sampai sekarang masih tetap eksis dilaksanakan dan sudah mendarah daging serta menjadi rutinitas bagi masyarakat jawa pada setiap tahunnya adalah sedekah bumi atau biasa dikenal dengan gas deso. Tradisi sedekah bumi ini, merupakan salah satu bentuk ritual tradisional masyarakat di pulau jawa yang sudah berlangsung secara turun temurun dari nenek moyang orang jawa jaman dahulu. Ritual bongkar bumi ini biasanya dilakukan oleh mereka pada masyarakat jawa yang berpotensi sebagai petani, nelayan yang menggantungkan hidup keluarga dan sanak saudara atau sanak keluarga mereka dari mengais riski dari memanfaatkan kekayaan alam yang ada di bumi.

Bagi masyarakat jawa khususnya para kaum petani dan para nelayan tradisi ritual turun temurun yang di adakan setahun sekali atau tahunan semacam bongkar bumi bukan hanya merupakan sebagai rutinitas atau ritual yang sifatnya tahunan belaka. Akan tetapi, tradisi sedekah bumi mempunyai makna yang lebih dari itu, upacara tradisional bongkar bumi itu sudah menjadi salah satu bagian yang sudah menyatu dengan masyarakat yang tidak akan mampu untuk dipisahkan dari budaya jawa yang menyiratkan symbol penjagaan terhadap kelestarian yang khas bagi masyarakat agraris maupun masyarakat nelayan khususnya yang ada di pulau jawa.

\section{METODOLOGI}

Metode penelitian yang digunakan dalam penelitian skripsi ini adalah metode penelitian kualitatif berdasarkan kajian lapangan yaitu dengan mengadakan observasi secara menyeluruh. Penelitian kualitatif adalah penelitian tentang riset yang bersifat deskriptif dan cenderung menggunakan analisis. Penelitian ini berlangsung selama 3 bulan dengan subjek penelitian tokoh masyarakat, tokoh agama, petani dan pemangku adat. Pengumpulan data dilakukan dengan mengadakan observasi secara menyeluruh, wawancara dan dokumentasi untuk mendapatkan informasi mengenai masalah yang diteliti.

\section{HASIL PENELITIAN DAN PEMBAHASAN}

\section{Acara Budaya Lokal Tradisi Bongkar Bumi di Desa Cupang Kecamatan Gempol Kabupaten Cirebon}


Pada waktu acara tersebut biasanya seluruh masyarakat sekitar yang merayakannya tradisi bongkar bumi membuat tumpeng dan berkumpul menjadi satu di balai desa, untuk menggelar acara ritual bongkar bumi tersebut. Setelah itu, tumpeng tersebut di do'akan oleh tetua adat. usai di do'akan oleh sesepuh atau tetua adat, kemudian kembali diserahkan kepada masyarakat setempat yang membuatnya sendiri. Nasi tumpeng yang sudah di do'akan oleh sesepuh kampung atau tetua adat setempat kemudian di makan secara ramai-ramai oleh masyarakat yang merayakan acara sedekah bumi itu dan selebihnya dibagikan kepada masyarakt. Namun, ada juga sebagian masyarakat yang membawa nasi tumpeng tersebut yang membawanya pulang untuk dimakan beserta sanak keluarganya di rumah masing-masing. Pembuatan nasi tumpeng ini merupakan salah satu syarat yang harus dilaksanakan pada saat upacara tradisi tradisional itu.

Puncak ritual Bongkar Bumi diakhiri dengan do'a yang dipimpin oleh ketua adat, lantunan do'a tersebut merupakan kolaborasi antara kalimatkalimat jawa dan lafal-lafal do'a yang bernuansa Islami, juga merupakan simbol penghormatan manusia terhadap tanah yang menjadi sumber kehidupan. Menurut anggapan masyarakat Jawa, dengan menggelar ritual Bongkar Bumi, tanah tidak akan marah seperti terjadinya gempa bumi, longsor maupun banjir. Adapun makna "essensial" yang terkandung dalam ritual ini manusia sebagai khalifah di bumi sepatutnya merenung kembali apa yang telah dilakukan untuk melestarikan bumi, memperhatikan, memperdulikan bumi dan tidak merusaknya sedikitpun, niscaya alam juga akan bersahabat dengan manusia.

\section{Bentuk dan Wujud Akulturasi Islam Pada Tradisi Bongkar Bumi}

Bentuk akulturasi dalam tradisi bongkar bumi di desa Cupang adalah pada rangkaian upacara tradisi bongkar bumi tersebut, yang mana dalam rangkaian upacara bongkar bumi tersebut terdapat perpadua antara budaya Hindu dan budaya Islam. Misalnya dalam hal pengadaan sesaji atau tumpeng yang dijadikan sarana untuk mensyukuri nikmat yang telah Allah berikan. Bukankah dalam agama Islam tidak mengenal sesaji, tetapi menurut penulis bahwa adanya sesaji atau atau tumpeng yang ada dalam 
upacara tradisi bongkar bumi merupakan manifestasi dari bentuk akulturasi antara budaya Hindu dengan Islam. Sesaji masih digunakan pada prosesi bongkar bumi, tapi fungsinya tidak seperti dahulu yang digunakan sebagai persembahan untuk dewa-dewa melaikan sebagai simbol bentuk syukur kepada Allah SWT ketika tahlilan pada prosesi pelaksanaan tradisi bongkar bumi. Kemudian hiburan yang ada dalam tradisi bongkar bumi adalah wayang kulit, yang mana wayang kulit tersebut merupakan salah satu bentuk akulturasi antara buday Hindu-Budha dengan Islam.

\section{Persepsi Masyarakat Terhadap Budaya Lokal Tradisi Bongkar Bumi}

Presepsi masyarakat desa Cupang mengenai tradisi bongkar bumi beragam, namun sebagian besar masyarkat menganggap masih pentingnya tradisi bongkar bumi ini untuk dilaksanakan, karena sebagai bentuk rasa syukur kita kepada Allah SWT yang telah melimpahkan Rahmat-Nya berupa rizki yang telah mereka peroleh. Tradisi upacara sedekah bumi merupakan salah satu contoh konkrit dari aplikasi fungsi solidaritas sebuah ritual (agama). Tradisi ini bertujuan agar kita selalu bersyukur atas segala nikmat yang telah diberikan oleh Tuhan dan saling menjaga solidaritas antar sesama manusia. Sehingga tercipta kerukunan dan kedamaian yang ada dimasyarakat desa Cupang. Dan ungkapan rasa syukur kepada Yang Maha Kuasa atas terlimpahnya rahmat, anugerah, dan kemakmuran yang telah diberikan kepada penduduk desa. Dan mengharapkan kemakmuran dan kesejahtraan masyarakat desa.

\section{E. KESIMPULAN DAN SARAN}

\section{Kesimpulan}

a. Bongkar bumi merupakan ritual sekaligus ekspresi budaya untuk menyambut musim tanam yang ada ditengah masyarakat suku Jawa. Bongkar bumi dilaksanakan dengan mengadakan pengajian di mesjid dan pementasan wayang kulit di hulu dayeuh yang merupakan bentuk penghormatan terhadap karuhun yang akan memberkati desa. Dalam konteks akulturasi budaya. Ritual ini dapat dikatakan sebagai perpaduan antara islam dengan budaya local, dalam konteks yang lebih sederhana 
Bongkar Bumi adalah ritual selamatan bumi dalam memohon perlindungan dan kesejahteraan dari yang maha hidup.

b. Bentuk akulturasi dalam tradisi bongkar bumi di desa Cupang adalah pada rangkaian upacara tradisi bongkar bumi tersebut, yang mana dalam rangkaian upacara bongkar bumi tersebut terdapat perpadua antara budaya Hindu dan budaya Islam. Seperti yang dapat dilihat dari bentuk do'a yang dikolaborasikan dengan kalimat- kalimat jawa dan dipadukan dengan kalimat-kalimat do'a yang bernuansa islami, Kemudian hiburan yang ada dalam tradisi bongkar bumi adalah wayang kulit, yang mana wayang kulit tersebut merupakan salah satu bentuk akulturasi antara buday Hindu-Budha dengan Islam.

c. Presepsi masyarakat desa Cupang mengenai tradisi bongkar bumi beragam, namun sebagian besar masyarkat menganggap masih pentingnya tradisi bongkar bumi ini untuk dilaksanakan, karena sebagai bentuk rasa syukur kita kepada Allah SWT yang telah melimpahkan Rahmat-Nya berupa rizki yang telah mereka peroleh. Dan dalam tradisi bongkar bumi juga mengandung nilai agama, sosial, ekonomi dan budaya. Salah satu pesan dari salah satu tokoh masyarakat desa Cupang pada saat dilaksanakan wawancara adalah" segala adat bisa diridhoi tapi sediki demi sedikit" ini berarti masyarakat mendukung adanya tradisi bongkar bumi tersebut, walau pada awalanya tradisi bongkar bumi ini jauh dari unsur islam, namun lambat laun tradisi ini berakulturasi dengan kebudayaan Islam.

\section{Saran}

Berdasarkan kesimpulan dan temuan pada penelitian yang telah dilakukan maka peneliti dapat memberikan saran sebagai berikut:

a. Untuk Masyarakat

Masyarakat dapat memberikan kontribusi dan kepedulian yang lebih besar terhadap tradisi bongkar bumi, sebagai kebudayaan yang harus dijaga dalam kehidupan sehari-hari, sehingga kelestariannya tetap terjaga sampai generasi-generasi berikutnya. Masyarakat juga diharapkan dapat 
membedakan antara kebudayaan Islam dan Hindu dan tidak mencampur adukan antara kebudayaan Islam dan Hindu.

b. Untuk Tokoh Adat

Peran aktif yang diberikan oleh masyarakat adat lebih besar seiring banyaknya budaya-budaya asing yang saat ini terus berkembang sehingga tidak dapat menggeser nilai-nilai agama, sosial dan budaya yang terdapat dalam tradisi bongkar bumi.

c. Untuk Generasi Muda

Agar generasi muda pada khususnya agar tetap mempertahankan tradisi bongkar bumi sebagai warisan nenek moyang, agar kita sebagai generasi muda tidak melupakan budaya yang diwariskan oleh para leluhur kita yang selanjutnya dapat dijadikan sumber ilmu dan wawasan dalam berbagai pengetahuna sosial.

d. Untuk Peneliti Selanjutnya

Peneliti selanjutnya diharpkan dapat mengkaji lebih dalam lagi mengenai budaya lokal tradis bongkar bumi yang selanjutnya dapat dijadikan sumber ilmu dan wawasan dalam berbagai pengetahuan sosial.

\section{DAFTAR PUSTAKA}

Abdurahman, Dudung, dkk. 2003. Pengantar Metode Penelitian. Yogyakarta: Kurnia Kalam Semesta.

Ahmad, Abu. 1999. Sosiolaogi Pendidikan. Jakarta: Rineka Cipta.

Elly M, dkk. 2006. Ilmu Sosial Budaya Dasar. Jakarta: Kencana.

Ghazali, Adeng Muchtar. 2011. Antropologi Agama (Upaya Memahami Keragaman Kepercayaan, Keyakinan, Dan Agama). Bandung: Alfabeta.

Kessing, Roger M.. 1992. Antropologi Budaya Suatu prespektif Kontemporer. Jakarta: Erlangga.

Kholil, Ahmad. 2011. Agama Kultural Masyarakat Pinggiran. Malang: UINMaliki Press.

Koentjaraningrat. 2005. Pengantar Antropologi. Jakarta: Rineka Cipta. 
Musyaraf. 2006. Islam Jawa, Kajian Fenomenal Tentang Pengaruh Islam dalam Budaya Jawa. Yogyakarta: Tugu Publisher.

Purwadi. 2005. Upacara Tradisional Jawa, Menggali Untaian Kearifan Lokal. Yogyakarta: Pustaka Pelajar.

Roibin. 2009. Relasi Agama dan Budaya Masyarakat Kontemporer. Malang: UIN-Malang Perss.

Tumanggoro, Rusmin dkk. Ilmu Sosila dan Budaya Dasar. Jakarta: Kencana. 